\title{
Loneliness and Problematic Internet Use (PIU) as Causes of Academic Procrastination
}

\author{
Esther Widhi Andangsari ${ }^{1}$, Achmad Djunaidi $^{2}$, Efi Fitriana $^{2} \&$ Diana Harding $^{2}$ \\ ${ }^{1}$ Psychology Department, Faculty of Humanities, Bina Nusantara University, Jakarta, Indonesia \\ ${ }^{2}$ Psychology Department, Universitas Padjadjaran, Bandung, Indonesia \\ Correspondence: Esther Widhi Andangsari. Jl. K.H. Syahdan No. 9, Palmerah, West Jakarta, Indonesia.
}

Received: December 4, 2017

doi:10.11114/ijsss.v6i2.2834

\author{
Accepted: January 19, $2018 \quad$ Available online: January 23, 2018 \\ URL: https://doi.org/10.11114/ijsss.v6i2.2834
}

\begin{abstract}
It is now undeniable that young people and the Internet has become inseparable. Nonetheless, the uncontrolled use of it causes many problems among young adults including academic procrastination. Previous studies stated that academic procrastination lead to low of academic achievement. The reason of why young adults use the internet excessively and got negative outcomes in academic life did not stated clearly. The objective of this study was to find out the empirical evidence of PIU as a mediator between loneliness and academic procrastination. Sample consisted of 320 undergraduate students from 10 universities. Age range was 17-25 years old ( $M=20.17, \mathrm{SD}=1.49)$. They were given three self-report questionnaires such as GPIUS2, SELSA, and TPS. Those instruments were adapted in Indonesian language. Data were analyzed with Structural Equation Modelling (SEM). The results showed that the model was good fit $(\chi 2=416.541$, $\mathrm{df}=205, \mathrm{p}<0.001, \mathrm{CFI}=0.902, \mathrm{TLI}=0.879, \mathrm{SRMR}=0.068, \mathrm{RMSEA}=0.057,90 \% \mathrm{CI}: 0.049-0.065$, p good to fit 0.05$)$. This study give contribution on loneliness, PIU, and academic procrastination as one model. It also gives implication of social media using among young people and policy making in universities about students life.
\end{abstract}

Keywords: academic procrastination, internet, loneliness, problematic internet use (PIU), young adults

\section{Introduction}

Observing the Internet use to date, it can be said that our daily activities has become inseparable from the Internet. Due to the prevalence of internet in our daily life, Internet has evolved to become a hero role to human as well as an enemy (Chamberlin, 2011). Internet users in the world had increased every year and the number achieved 3.2 billion users by the end of 2015 (Internet Society, 2016). Meanwhile, the Internet users in Indonesia until 2016 have amounted to 132.7 million users with 129.2 million $(97,4 \%)$ among them were active social media users (Indonesia Internet Service Provider Association, 2016). The prevalence of Internet use among young people had problems accompanying it. The Internet application such as social media, which became the most accessed application by youth in Indonesia, made them seemingly inseparable from it. Since the emergence of smartphones, it seems that the young people are fixated to social media or the Internet. They stick to the Internet and skip their academic task. It was known that many students tend to do academic procrastination (Rothblum, Salomon, \& Murakami,1986). Half of the individuals that had problems related to the internet use also had problems in their jobs or their academics caused by their spending time to go online and opted to procrastinate working on their assignments until the last minute (Yellowless \& Marks, 2007).

Regarding of social media use, it is found that procrastination is resulted from Facebook use excessively (Przepiorka, Blachnio, \& Diaz-Morales, 2016; Meier, Reinecke, \& Meltzer, 2016). As observed phenomenon, young people always stick to the Internet and it is assumed they may have problem with it, not only in academic area but also in clinical psychology area. They would have Problematic Internet Use (PIU) as multi-syndrome of internet maladaptive usage (Caplan, 2002; Davis, 2001). PIU is resulted from maladaptive cognition pairing with behavioral maladaptive thus the person showed maladaptive response such as procrastination (Davis, 2001; Davis, Flett, \& Besser, 2002). Young people need for social contact but some of them with loneliness would have difficulty to have one. They need media such as internet to help them fulfill their need for social contact. Unfortunately, people with this psychological vulnerability have problematic cognition and lead to behavioral maladaptive. They would have PIU and the dependency on the Internet leads them to academic problem. 


\subsection{Academic Procrastination in the Internet Activities}

Based on the Rothblum, Salomon, and Murakami (1986), it was known that many students had committed academic procrastination. Half of the individuals that had problems related to the internet use also had problems in their jobs or their academics caused by their spending time to go online and opted to procrastinate working on their assignments until the last minute (Yellowless \& Marks, 2007). The students committed the academic procrastination within the scope of writing a paper, studying for the exam, and doing weekly readings (Solomon \& Rothblum, 1984). The previous study showed that there was a positive and significant correlation between academic procrastination to PIU in students (Mohammad, Tahriri, \& Hassaskhah, 2015).

Previous study showed that two symptoms of PIU are negative life consequence and preoccupation with the Internet, become the indicators to the worsening academic performance of the overuse of Internet within adolescence (Leung \& Lee, 2012). As a consequence of the overuse of the Internet, the students avoid or intentionally skip schools and, of course, this affect their academic performance (Kubey, Lavin, \& Barrows, 2001; Leung \& Lee, 2012). For undergraduate students, the excessive internet uses also impact on their exacerbating academic performance (Derbyshare et.al., 2013). Davis, Flett, and Besser (2002) state that individuals with PIU, which also negatively affecting their GPA, lead to procrastination. It is understood that individuals with PIU symptoms are individuals that make Internet as the only means that comprehend themselves (Davis, 2001). Thus, the indi viduals will be occupied with the Internet use and neglect their other responsibilities including academic responsibility.

Why do students do academic procrastination? Based on Steel and Klingsieck (2016) there are four aspects has role as antecedence of academic procrastination. First antecedence is personality trait (Steel \& Klingsieck, 2016), such as neuroticism is find as a source of procrastination because of anxious trait lead to procrastinate action (Steel, 2007), and procrastination become the way to avoid anxiety (Steel, Brothen, \& Warmbach, 2001). Second antecedence is motivational aspects and volitional aspects including lack of self-control (Steel \& Klingsieck, 2016; Tuckman, 1991). Third antecedence is clinical aspects such as depression, anxiety, and stress. And the fourth antecedence is situational aspect such as task characteristics and teacher characteristics (Steel \& Klingsieck, 2016). It is understood that academic procrastination has complex antecedence. It can be assumed that academic procrastination is not simple maladaptive behavior as common people thought. Observed phenomenon that academic procrastination is done by students, not because of their inability in doing the task or understand the subject matter. But there is something that is "empty" in them in the midst of the human-computer relationship in internet activities. The emptiness is a symptom of loneliness because individual judgment regarding the absence of relationships with others (Perlman \& Peplau, 1981). Previous research shows a connection between loneliness and academic procrastination (Malik \& Rafiq, 2015). Based on the knowledge of the authors, research on loneliness and academic procrastination still in small number. To fill this small number of research in this area and related on the phenomenon, the authors focused this study on the clinical aspect as antecedence of academic procrastination.

\subsection{Academic Procrastination, Loneliness, and Problematic Internet Use (PIU)}

The term 'procrastination' refers to "voluntarily delay to intended course of action despite expecting to be worse off for the delay" (Steel, 2007, p. 66), or the tendency avoids an action that someone should control it (Tuckman, 1991). The person has capability to do the task, but does not have self-efficacy with his capability and intensively delay doing the task (Tuckman, 1991). It is understood that procrastination is an action that purposely or intensively to do it and have bad consequence because of it. While academic procrastination is procrastination related to study or academic area (Steel \& Klingsieck, 2016). The scopes of academic procrastination in students are writing a paper, studying for the exam, and doing weekly readings (Solomon \& Rothblum, 1984). The academic procrastination gives negative consequences to the students related to their academic performance and subjective well-being (Steel \& Klingsieck, 2016), including lower grades (Steel, Brothen, \& Wambach, 2001).

Loneliness is a response or the absence of interpersonal an unpleasant feeling caused by the diminishing interpersonal relationship both quantitatively and qualitatively (Weiss, 1973 as cited in Peplau \& Perlman, 1982; Perlman \& Peplau, 1981). This research used loneliness concept as the multidimensional construct which consisted of two types: emotional loneliness (the absence of interpersonal relationship with a figure who is close emotionally); social loneliness (the absence of interpersonal relationship with a wider social sphere) (Weiss, 1973, as cited in Ernst \& Cacioppo, 1999; De Jong Gievrvald \& Tilburg, 2006; De Jong Giervald, Tilburg, \& Dykstra, 2006; Tharayil, 2012). The conditions associated with excessive Internet use, or dependence on the Internet among the students, could make them experiencing Problematic Internet Use (PIU). Some studies reported that there was a relationship between loneliness with PIU (Caplan, 2002; Morahan-Martin \& Schumacher, 2003; Song, Zymslinski-Seelig, Kim, Drent, Victor, \& Omori, 2014; Andangsari \& Dhowi, 2016). Loneliness becomes the antecedence of PIU or it has the role as prior psychopathology to PIU (Davis, 2001; Caplan, 2002; Griffiths, Kuss, Billieux, \& Pontes, 2016). Loneliness also 
enhances a psychological condition that needed to be attended considering that at the future it can become a threat to the mental health for young people (Holt-Lundstat, Baker, Harris, \& Stephenson, 2015). Therefore, young adults that experienced loneliness will use Internet as an escape mechanism or a form of saving themselves from the nonexistent social interaction which they experienced. Unfortunately, this vulnerable condition would apparently give rise to PIU symptom and induced academic procrastination (Malik \& Rafiq, 2015).

The PIU concept coined by Davis (2001) was the model that explained PIU using a behavior cognitive approach (Young, Yue, \& Ying, 2011). Davis explained that PIU was a consequence from prior physiological problem that initially had been present in a person (Davis, 2001). This condition was referred to as a distal contributory causal of PIU such as social anxiety, depression, loneliness, and substance dependence (Davis, 2001; Griffiths, Kuss, Billieux, \& Pontes, 2016) that followed concept of psychopathology (diathesis) and live event (stress) (Davis, 2001). As a result, individuals with existing psychopathological and their diathesis-stress experience were considered by Davis would experience maladaptive cognition and negative outcome in their internet use behavior. This was referred to as proximal contributory of PIU (Davis, 2001; Griffiths, Kuss, Billieux, \& Pontes, 2016).

\subsection{Purpose of the Study}

It is stated clearly above that prior psychopathology such as loneliness has a role for antecedence of PIU. A lonely person has lack of interpersonal skill and but still motivation to connect with others via online. Unfortunately, his maladaptive cognition leads to compulsive use of internet (Davis, 2001) and facing PIU. Then PIU gives consequence to academic procrastination. It is also already stated above that one of the antecedence of academic procrastination is clinical aspect (Steel \& Klingsieck, 2016) such as loneliness (Malik \& Rafiq, 2015). It gives clear path that there is a connection between loneliness, PIU, and academic procrastination. Previous study finds out that there is a correlation between loneliness and PIU and it gives impact on academic procrastination (Malik \& Rafiq, 2015). It already proved that PIU gives impact to academic procrastination (Malik \& Rafiq, 2015; Mohammadi, Tahriri, \& Hassaskhah, 2015). But the study did not state clearly about the role of PIU as mediator between this relationship. This study gives contribution to empirical evidence on PIU as mediator of loneliness and academic procrastination, that previous studies did not show it. Then the hypothesis of this study is: the model of PIU as a mediator to the relation betwe en loneliness and academic procrastination is fit with the data.

\section{Method}

This study was conducted to undergraduate students by giving self-report instruments. In this section, the authors describe about description of the participants, the measures use in the study, and data analyzed.

\subsection{Participants}

Study was conducted on 320 undergraduate students with age range 17-25 years old (M=20.17, SD=1.49), and consist of 170 females $(53.1 \%)$ and 150 males (46.9\%). The respondents originated from ten universities in which had good rank in Jakarta. Thus, it was assumed to have some adequate internet facilities for learning processes, including Internet facility.

Researcher assistants asked the willingness of respondents through lecturers or directly requested the respondents in every lecture class they participated. The respondents filled out the self-report questionnaires inside class and were explained how to fill out the questionnaires by researcher assistants. After filling out the questionnaires, the respondents were given appreciation token.

\subsection{Measures}

\subsubsection{SELSA (Social and Emotional Loneliness Scale for Adults)}

SELSA measuring tools were applied to measure loneliness that had multidimensional characteristic (DiTommaso \& Spinner, 1993). This instrument was a self-report questionnaire which consisted of 2 dimensions, i.e: Emotional Scale (consists of romantic subscale and family subscale) and Social Scale with 37 items. Respondents were asked to respond to those items in 7-point scale: 1(strongly disagree), 2(disagree), 3(somewhat disagree), 4 (no label), 5 (somewhat agree), 6 (agree), 7(strongly agree). Item in the Emotional Scale, for example: "I am an important part of someone else's life", "No one in my family really cares about me". Item on Social Scale, for example: "I don 't have a friend(s) who shares my views, but I wish I did", "I feel a part of a group of friends". The overall items in SELSA had been initially adapted into Indonesian language and had been tested by validity construct through Confirmatory Factor Analysis (CFA) with a valid result for the three subscales: romantic subscale $\left(\chi^{2}=16.94, \mathrm{df}=15, \mathrm{p}\right.$-value $=0.32231$, RMSEA $=0.020)$; family subscale $\left(\chi^{2}=23.79, \mathrm{df}=21, \mathrm{p}\right.$-value $=0.30334$, RMSEA $\left.=0.020\right)$; social scale $\left(\chi^{2}=70.64, \mathrm{df}=54\right.$, p-value $=0.06375$, RMSEA $=0.031$ ) (Andangsari $\&$ Dhowi, 2016). The CFA results recommended eliminating 3 items which are item no. 11,12 , and 15 . The reability of this instrument was $\alpha=0.820$ for emotional loneliness (romantic and family subscale) and $\alpha=0.843$ for social loneliness. 


\subsubsection{GPIUS2 (Generalized Problematic Internet Use Scale 2)}

The PIU measurement was conducted through self-report questionnaire GPIUS2 (Caplan, 2010). This instrument consisted of 5 dimensions, i.e: POSI (Preference for Online Social Interaction), mood regulation, cognitive preoccupation, compulsive internet use, and negative outcomes. Respondents were asked to respond to the 15 items through 8-point scale ranging from 1 (definitely disagree) to 8 (definitely agree). The example items on GPIUS2 among others, were "I prefer online social interaction over face to face communication", "I have used the Internet to talk with others when I was feeling isolated", "I have difficulty controlling the amount of time I spend online". Before given to the respondents, this instrument was, at first, adapted into Indonesian language and tested by the construct validity test through CFA with a valid result $\left(\chi^{2}=72.07, \mathrm{df}=58, \mathrm{p}\right.$-value $=0.0125, \mathrm{RMSEA}=0.028$ (Andangsari \& Dhowi, 2016). The reliability of this instrument was $\alpha=0.906$.

\subsubsection{TPS (Tuckman Procrastination Scale)}

This procrastination academic measurement was conducted through the self-report questionnaire TPS (Tuckman, 1991) which consisted of 16 items, which were a short-form type from 35 items on the Procrastination Scale instrument. This questionnaire had 4-point scale ranging from 1(strongly disagree) to 4(strongly agree). The item examples on TPS were for example: "I postpone starting in on things I don't like to do", "I am an incurable time waster", "I always finish important jobs with time to spare". Like these two instruments that were explained above, these questionnaires, thus, also, at first, adapted into Indonesian language and were tested by using construct validity test through CFA. The calculation result of $\mathrm{CFA}$ was $\chi^{2}=146.746, \mathrm{df}=95, \mathrm{p}$-value $=0.000, \mathrm{RMSEA}=0.049$. Therefore, it could be conveyed that the adaption instrument was valid and usable in the data gathering. Based on the calculation result of construct reliability, the result acquired was 0.85 .

\subsection{Control Variables}

The respondents were also asked to fill out the questions related to their condition themselves as control variables. For example, the recent GPA score, the average of daily internet use time duration, the average of internet expenses every month, the total social media used, also whether they activate the social media notification in their smartphones. Those questions needed to be proposed to delve into the condition of the undergraduate students who were internet users. The information about the highest internet use in Indonesia for accessing the social media, making it a need to propose questions about the total number of social media owners and the notification of their social media in the smartphone. Questions about the most recent GPA score needed to be proposed regarding to the academic procrastination measurement.

\subsection{Data Analysis}

The completed questionnaires by the respondents were collected by research assistants and inputted into computer. The hypothetical analysis was conducted through the Structural Equation Model (SEM) testing with the assistance from MPlus software. Meanwhile, the demographic data analysis was conducted through descriptive analysis and Spearman Correlation calculation with help from SPSS software.

\section{Results}

\subsection{Descriptive Measurement}

The descriptive measurement results covered GPA respondents, the monthly internet expenses, the average of time spent online every day, the total of social media used, and the social media notification activation in the respondent's smartphone can be observed on the table 1 . 
Table 1. Control Variable Data $(\mathrm{N}=320)$

\begin{tabular}{|c|c|c|c|c|}
\hline & & & $\mathrm{N}$ & $\%$ \\
\hline \multirow[t]{5}{*}{ GPA } & (1) & Less than 2.00 & 1 & 0.3 \\
\hline & $(2)$ & $2.00-2.50$ & 20 & 6.3 \\
\hline & (3) & $2.51-3.00$ & 116 & 36.3 \\
\hline & (4) & Above 3.00 & 179 & 55.9 \\
\hline & Miss & ing data & 4 & 1.3 \\
\hline \multirow{6}{*}{$\begin{array}{l}\text { Average internet expenses every } \\
\text { month }\end{array}$} & (1) & $50.000,00-100.000,00$ IDR & 172 & 53.8 \\
\hline & & 100.000,00-200.000,00 IDR & 82 & 25.6 \\
\hline & (3) & $200.000,00-300.000,00 \mathrm{IDR}$ & 39 & 12.2 \\
\hline & (4) & $300.000,00-400.000,00$ IDR & 14 & 4.4 \\
\hline & (5) & $400.000,00-500.000,00$ IDR & 6 & 1.9 \\
\hline & (6) & more than $500.000,00$ IDR & 7 & 2.2 \\
\hline \multirow[t]{5}{*}{ Average time spent online every day } & (1) & less than 1 hour/day & 42 & 13.1 \\
\hline & (2) & 1-2 hours/day & 62 & 19.4 \\
\hline & (3) & 2-3 hours/day & 57 & 17.8 \\
\hline & (4) & 3-4 hours/day & 62 & 19.4 \\
\hline & (5) & 4-5 hours/day & 48 & 15.0 \\
\hline \multirow[t]{6}{*}{ Amount of social media } & (1) & have one(s) but not active ${ }^{-}$ & 44 & 13.8 \\
\hline & (2) & 1 active social media & 79 & 24.7 \\
\hline & (3) & 2 active social media & 116 & 36.3 \\
\hline & (4) & 3 active social media & 55 & 17.2 \\
\hline & (5) & 4 active social media & 19 & 5.9 \\
\hline & (6) & 5 active social media & 7 & 2.2 \\
\hline \multirow{2}{*}{$\begin{array}{l}\text { Social media notification activation } \\
\text { on smartphone }\end{array}$} & (1) & Yes & 283 & 88.4 \\
\hline & (2) & No & 37 & 11.6 \\
\hline
\end{tabular}

Note: missing data means the respondent did not fill in the GPA value. IDR=Indonesian Rupiah

Based on the table 1 for GPA, it could be inferred that the mode of the GPA from the respondent's group placed on above 3.00 GPA range. Meanwhile, related to the online behavior of the respondents, it could have inferred that the mode for average monthly internet expense was around 50,000 - 100,000 IDR, which was the lowest monthly internet expense category in this research.

Based on the average time spent online every day, the highest percentage indicated by the less than 1hour/day and 3-4 hours/day category. Considering the information from Indonesia Internet Service Provider Association (2015), that on average Indonesian people used internet every day about 1-3 hours. Therefore, the data from table 1 could be interpreted that there was a balance of total respondents' percentage who used internet below the internet use of average Indonesian people and who exceeded the Internet use of average Indonesian people. The brimming variants of social media types that entered Indonesia made us interested on to look on the data related to the total active social media which we re used and the social media notification activation in smartphone. The Internet use has also become increasingly prevalent related to the use of mobile device including smartphone (Internet Society, 2014). The research result indicated that the mode of the total of social media accounts used, placed into the social media category 2 . The interesting part from the data in table 1 is that majority of the respondents activated the social media account notification on individual smartphone. It can be understood that the respondents were quite "busy" observing their social media through their smartphones, especially when they had more than two social media accounts and all of its notifications were activated.

\subsection{Correlation Result}

The correlation result between the control variables, loneliness, PIU, and academic procrastination as written on table 2. 
Table 2. Correlation between control variables, loneliness, PIU, academic procrastination $(\mathrm{N}=320)$

\begin{tabular}{|c|c|c|c|c|c|c|c|c|c|c|c|}
\hline & & Mo & M & $\mathrm{SD}$ & 1 & 2 & 3 & 4 & 5 & 6 & 7 \\
\hline 1 & GPA & above 3.00 & - & - & 1 & & & & & & \\
\hline 2 & $\begin{array}{l}\text { Internet } \\
\text { expenses }\end{array}$ & $\begin{array}{l}50.000,00-100.000,0 \\
0 \text { IDR }\end{array}$ & - & - & 0.016 & 1 & & & & & \\
\hline 3 & $\begin{array}{l}\text { Time spent } \\
\text { online }\end{array}$ & 1-2 hours/day & - & - & 0.072 & $\begin{array}{c}0.113 \\
*\end{array}$ & 1 & & & & \\
\hline 4 & $\begin{array}{l}\text { Amount of } \\
\text { Social Media }\end{array}$ & 2 active social media & - & - & $\begin{array}{c}-0.03 \\
7\end{array}$ & $\begin{array}{c}0.143 \\
*\end{array}$ & $\begin{array}{c}0.233^{*} \\
*\end{array}$ & 1 & & & \\
\hline 5 & $\begin{array}{l}\text { Emotional } \\
\text { Loneliness }\end{array}$ & - & $\begin{array}{c}75.5 \\
6\end{array}$ & $\begin{array}{c}13.6 \\
0\end{array}$ & $\begin{array}{c}-0.08 \\
5\end{array}$ & -0.003 & $-0.124 *$ & $0.130^{*}$ & 1 & & \\
\hline 6 & $\begin{array}{l}\text { Social } \\
\text { Loneliness }\end{array}$ & - & $\begin{array}{c}41.8 \\
5\end{array}$ & $\begin{array}{c}11.2 \\
4\end{array}$ & $\begin{array}{c}-0.11 \\
7\end{array}$ & -0.029 & $-0.110^{*}$ & $\begin{array}{c}0.177^{*} \\
*\end{array}$ & $\begin{array}{l}0.580^{*} \\
*\end{array}$ & 1 & \\
\hline 7 & PIU & - & $\begin{array}{c}56.9 \\
5\end{array}$ & $\begin{array}{c}18.7 \\
2\end{array}$ & 0.029 & 0.066 & -0.044 & $\begin{array}{c}0.226^{*} \\
*\end{array}$ & $\begin{array}{c}0.248^{*} \\
*\end{array}$ & $\begin{array}{c}0.299 * \\
*\end{array}$ & 1 \\
\hline 8 & $\begin{array}{l}\text { Academic } \\
\text { Procrastinatio } \\
\mathrm{n}\end{array}$ & - & $\begin{array}{c}38.9 \\
8\end{array}$ & 5.28 & 0.003 & 0.054 & 0.088 & $0.136^{*}$ & $\begin{array}{l}0.298^{*} \\
*\end{array}$ & $\begin{array}{c}0.212 * \\
*\end{array}$ & $\begin{array}{c}0.289 * \\
*\end{array}$ \\
\hline
\end{tabular}

Note: $* \mathrm{p}<0.05, * * \mathrm{p}<0.01$, IDR=Indonesian Rupiah

Based on the calculation result using the measurement tools such as SELSA, GPIUS2, and TPS, then, here was the calculation result of the descriptive statistics obtained as written on table 3 .

Table 3. The result of descriptive statistics calculation using measurement tools: SELSA, GPIUS2, TPS

\begin{tabular}{|c|c|c|c|}
\hline Instruments & Dimension & M & $\mathrm{S}$ \\
\hline SELSA (Social and Emotional Loneliness & & 117.40 & 21.90 \\
\hline Scale for Adults) & Emotional Scale (EL) & 75.56 & 13.60 \\
\hline & Social Scale (SL) & 41.85 & 11.24 \\
\hline GPIUS2 (Generalized Problematic Internet & & 56.95 & 18.72 \\
\hline Use Scale 2) & Preference for Online Social Interaction (POSI) & 10.50 & 4.72 \\
\hline & Mood Regulation (MR) & 12.13 & 4.76 \\
\hline & Cognitive Preoccupation (CP) & 12.27 & 4.68 \\
\hline & Compulsive Internet Use (CIU) & 11.58 & 4.77 \\
\hline & Negative Outcomes (NO) & 10.48 & 4.62 \\
\hline TPS (Tuckman Procrastination Scale) & & 38.98 & 5.28 \\
\hline
\end{tabular}

\subsection{Hypothesis Testing Result}

The model that was tested in this research as in the picture 1 below.

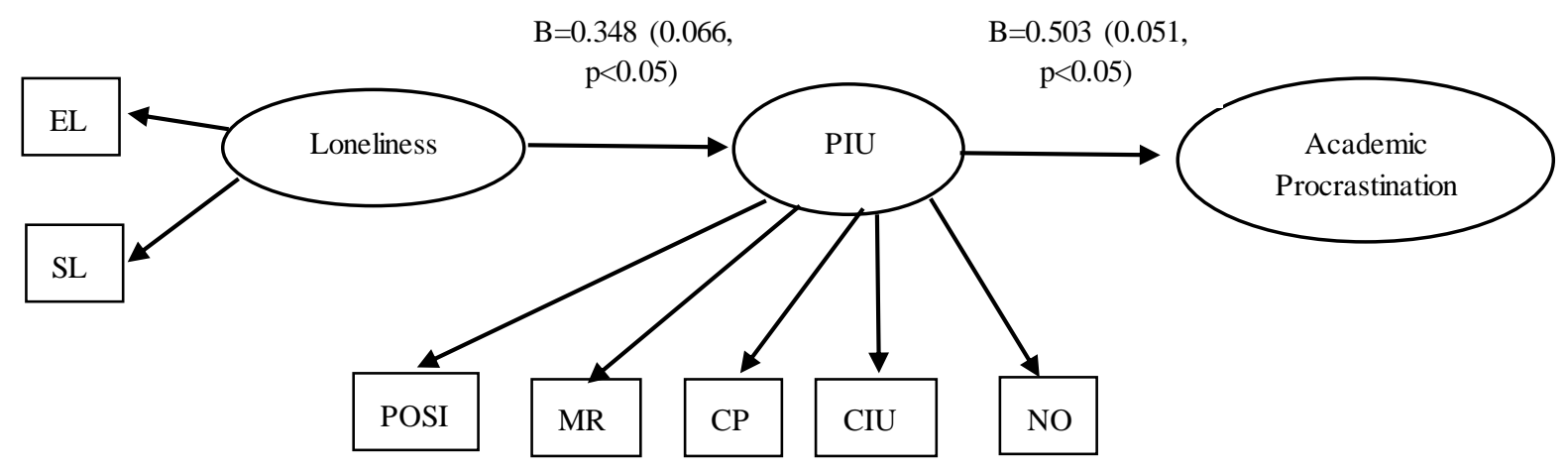

Figure 1. The Structure Model 
The result of SEM calculation can be observed from table 4 .

Table 4. Regression result between Loneliness, PIU, and Academic Procrastination

\begin{tabular}{llllll}
\hline No & \multicolumn{1}{c}{ Model } & $\beta$ & ES & p-value & Significant \\
\hline 1 & Loneliness $\rightarrow$ PIU & 0.348 & 0.066 & 0.000 & Significant \\
2 & PIU $\rightarrow$ Academic Procrastination & 0.503 & 0.051 & 0.000 & Significant \\
3 & $\begin{array}{l}\text { Loneliness } \rightarrow \text { Emotional } \\
\text { Loneliness (EL) }\end{array}$ & 0.661 & 0.079 & 0.000 & Significant \\
4 & $\begin{array}{l}\text { Loneliness } \rightarrow \text { Social Loneliness } \\
\text { (SL) }\end{array}$ & 0.881 & 0.089 & 0.000 & Significant \\
5 & $\begin{array}{l}\text { PIU } \rightarrow \text { Preference for Online } \\
\quad \text { Social Interaction (POSI) }\end{array}$ & 0.595 & 0.041 & 0.000 & Significant \\
6 & PIU $\rightarrow$ Mood Regulation (MR) & 0.639 & 0.038 & 0.000 & Significant \\
7 & $\begin{array}{l}\text { PIU } \rightarrow \text { Cognitive Preoaccupation } \\
\text { (CP) }\end{array}$ & 0.794 & 0.026 & 0.000 & Significant \\
8 & $\begin{array}{l}\text { PIU } \rightarrow \text { Compulsive Internet Use } \\
\text { (CIU) }\end{array}$ & 0.869 & 0.021 & 0.000 & Significant \\
9 & PIU $\rightarrow$ Negative Outcomes (NO) & 0.769 & 0.028 & 0.000 & Significant \\
\hline
\end{tabular}

Notes: ES= Error Standard, PIU=Problematic Internet Use

From the figure 1 and table 4, it can be viewed that PIU acted as the relationship mediator between loneliness with academic procrastination. It also indicated that all the observed variables gave significant correlation with the latent variables. Thus, derived from the structure model, it could be performed an SEM calculation to test the proposed hypothesis. The calculation result indicated that the entire relationship between the three variables significantly and positively correlated. It was proven that there was an influence of loneliness on PIU. PIU was also proven to affect academic procrastination. Afterwards, based on the SEM calculation result concerning the loneliness influence model to academic procrastination with PIU mediation, the result obtained (Hu \& Bentler, 1999) was good fit $(\chi 2=416.541$, d.f. $=205$, p $<0.001$, CFI=0.902, TLI=0.879, SRMR=0.068, RMSEA=0.057, 90\% CI:0.049-0.065, p good fit 0.05). From this calculation, it could be inferred that the structure model fitted with the data. 0.079 . The indirect model result was $\beta=0.009, E S=0.002, p<0.005$. Therefore, it could be asserted that there was an influence between loneliness and academic procrastination which was mediated by the PIU. PIU had been proven to become the loneliness medium to academic procrastination. The lonelier the students, the more they would experience PIU and it impacted on the academic procrastination.

\section{Discussion}

The model fit with data, it means that PIU is proved to be an influence mediator between loneliness and academic procrastination, that consistent with study from Malik and Rafiq (2015). It also consistent with Steel and Klingsieck (2016) that clinical aspects (including loneliness) become antecedence of academic procrastination. In other way, it indicates that individuals that underwent loneliness usually have problems with concentration (Perlman \& Peplau, 1981), namely they who focused on establishing relationship with others but unfocused on working on their academic activities or studying. That loneliness feeling make them less motivated to the academic activities, and only feel motivated to build relationship with others (online) but lost the motivation to do other tasks. As a consequence, they neglect their jobs as an undergraduate student.

The research result showed the existence of loneliness' influence that affected the PIU was consistent with previous research from Caplan (2002), Morahan-Martin (2003), Song, Zymslinski-Seelig, Kim, Drent, Victor, and Omori (2014), also Andangsari and Dhowi (2016). The lonely students had a maladaptive cognition (Davis, 2001). Students in digital era were accustomed to build a friendship relation by online. The students would utilize the internet as means to overcome their limitation. It was that only the maladaptive cognition of lonely person which made them thought that only through internet they can get fun to establish relationship (Davis, 2001).

It can be concluded that this study give contribution to explanation about relation between loneliness, PIU, and academic procrastination as one model. The relations between three variables are clearly. It can be understood that the reason students do academic procrastination is not only because of PIU, but also because of loneliness. This paper gives clear explanation about the clinical aspect on academic procrastination and the link between loneliness and academic procrastination through PIU.

Regarding of the clinical aspect on academic procrastination, the Universities should make some programs to prevent the dangerous of loneliness as the implication of the study. The institution also needs to consider the policy making of social media using among their students in campus life. It was proved that loneliness lead to PIU and PIU lead to academic procrastination. Social media can be used as tool for fulfill the need of social contact. But at the same time, it 
also gives like a "trap" for young people with clinical problems and academic problems. Since young people cannot separate with social media, then it would be wise to give education on use social media in a positive or healthy way for them.

This study was taken in Jakarta, capital city in Indonesia. Jakarta has known as a metropolitan city. Results of this study were representative of young people's life in a busy city. But the authors also suggest doing the research in another city in Indonesia especially the cities outside of Java Island.

This study has a limitation on the data extraction on the students' GPA. In this research, the students only asked to fill out their own GPA by themselves. The authors couldn't verify their GPA scores due to the access limitation to perform the check. It would be a good idea for the next research, to pay attention to the respondents' GPA balance (low to high scores). Another limitation is the sample of this study is not a clinical sample. The researchers need to find out the similar research with clinical sample for the future research. Again, for future research, it should consider other factors which would become indicator for the PIU's emergence and academic procrastination which would come from internal portion of students and their external portion (example: university policy, parents'roles).

\section{Acknowledgements}

Some parts of this paper have already presented in The Asia Pacific Research in Social Sciences and Humanities (APRISH) Universitas Indonesia Conference, in November 2016. The authors would like to express deep gratitude to the involvement of the research assistants in the data extraction process in this research. A thank-you-note would be addressed to Bay Dhowi, Desy Permatasari, Ahmad Ghozali, Afiati, Nurchayati, Raebella Angesti, and Fadjri Verdiansyah.

\section{References}

Andangsari, E. W., \& Dhowi, B. (2016). Two Typology Type of Loneliness and Problematic Internet Use (PIU): An Evidence of Indonesian Measurement. Advanced Science Letters, 22, 1711-1714. https://doi.org/10.1166/as1.2016.6740

Asosiasi Penyelenggara Jasa Internet Indonesia. (2015). Profil Pengguna Internet Indonesia 2014. Jakarta: APJII. Retrieved May 19, 2015, from https://apjii.or.id/content/read/39/27/PROFIL-PENGGUNA-INTERNET-INDONESIA-2014

Caplan, S. (2002). Problematic internet use and psychosocial well-being development of a theory-based-cognitive-behavioral measurement instrument. Computers in Human Behavior, 18(2002), 553-575. https://doi.org/10.1016/S0747-5632(02)00004-3

Caplan, S. E. (2003). Preference for Online Social Interaction: A Theory of Problematic Internet Use and Psychological Well-Being. Communication Research, 30(6), 625-648. https://doi.org/10.1177/0093650203257842

Caplan, S. E. (2010). Theory and measurement of generalized problematic internet use: A two-step approach. Computers in Human Behavior, 26(2010), 1089-1097. https://doi.org/10.1016/j.chb.2010.03.012

Chamberlin, J. (2011, Ocotber ). Facebook: friend or foe? Monitor on Psychology, 42(9), 66-67.

Davis , R. A. (2001). Acognitive-behavioral model of pathological internet use. Computers in Human Behavior, 17(2001), 187-195. https://doi.org/10.1016/S0747-5632(00)00041-8

Davis, R. A., Flett, G. L., \& Besser, A. (2002). Validation of a New Scale for Measuring Problematic Internet Use: Implications for Pre-remployment Screening. Cyberpsychology \& Behavior, 5(4), 331-345. https://doi.org/10.1089/109493102760275581

De Jong Garveld, J., \& Tilburg, T. V. (2006). A6-Item Scale for Overall, Emotional and Social Loneliness. Research in Aging, 28(5), 582-598. https://doi.org/10.1177/0164027506289723

De Jong Garveld, J., Tilburg, T. V., \& Dysktra, P. A. (2006). Loneliness and Social Isolation. In A. Vangelisti, \& D. Perlman (Eds.), Cambridge Handbook of Personal Relationships (pp. 485-500). Cambridge: Cambridge Uni versity Press. https://doi.org/10.1017/CBO9780511606632.027

Derbyshare, K. L., Lust , K. A., Schreiber , L. R., Odlaug, B. L., Christenson, G. A., Golden, D. J., \& Grant , J. E. (2013). Problematic Internet use and associated risk in a college sample. Comprehensive Psychiatry, 54(2013), 415-422. https://doi.org/10.1016/j.comppsych.2012.11.003

DiTommaso, E., \& Spinner, B. (1993). The De velopment and Initial Validation of The Social and Emotional Loneliness Scale for Adults (SELSA). Person. Individ. Diff, 14(1), 127-134. https://doi.org/10.1016/0191-8869(93)90182-3

Ernst, J. M., \& Cacioppo, J. T. (1999). Lonely heart: Psychological perspectives on loneliness. Applied \& Preventive 
Psychology, 8(1999), 1-22. https://doi.org/10.1016/S0962-1849(99)80008-0

Griffiths, M. D., Kuss, D. J., Billieux, J., \& Pontes, H. M. (2016). The evolution of Internet addiction: A global perspective. Addictive Behaviors, 53(2016), 193-195. https://doi.org/10.1016/j.addbeh.2015.11.001

Hold-Lundstat, J., Baker, M., Harris, T., \& Stephenson, D. (2015). Loneliness and Social Isolation as Risk Factors for Mortality: A Meta-Analytic Review. Perception on Psychological Sciences, 10(2), 227-237.

Hu, L. T., \& Bentler, P. M. (1999). Cutoff criteria for fit indexes in covariance structure analysis: Conventional criteria versus new alternatives. Structural Equation Modeling: A Multidisciplinary Journal, 6(1), 1-55. https://doi.org/10.1080/10705519909540118

Internet Society. (2015). Internet Society. Global Report 2015. Mobile Evaluation and Development of the Internet. Switzerlad: Internet Society. Retrieved September 15, 2016, from http://internetsociety.org/globalinternetreport/

Kubey, R. W., Lavin, M. J., \& Barrows, J. R. (2011). Internet use and collegiate academic performance decrements: Early Findings. Journal of Communication, 51(2), 366-382. https://doi.org/10.1111/j.1460-2466.2001.tb02885.x

Leung, L., \& Lee, P. S. (2012). Impact of Internet Literacy: Internet Addiction Symptoms, and Internet Activities on Academic Performance. Social Science Computer Review, 30(4), 403-418. https://doi.org/10.1177/0894439311435217

Malik, A. U., \& Rafiq, N. (2015). Exploring the Relationship of Personality, Loneliness, and Online Social Support with Interned Addiction and Procrastination. Pakistan Journal of Psychological Research, 31(1), 93-117.

Meier, A., Reinecke, L., \& Meltzer, C.E. (2016). "Facebocrastination"? Predictors of using Facebook for procrastination and its effects on students' well-being. Computers in Human Behavior, 64(2016), 65-76. https://doi.org/10.1016/j.chb.2016.06.011

Mohammadi, M., Tahriri, A., \& Hassaskhah, J. (2015). The Relationship between Internet Use and Academic Procrastination of EFL Learners across Years of Study. International Journal of Applied Linguistics \& English Literature, 4(1), 231-241.

Morahan-Martin, J., \& Schumacher, P. (2003). Loneliness and Social Uses of the Internet. Computers in Human Behavior, 19(2003), 59-671. https://doi.org/10.1016/S0747-5632(03)00040-2

Peplau, L. A., \& Perlman, D. (1982). Perspective on Loneliness. In L. A. Peplau, \& D. Perlman (Eds.), Loneliness: A Sourcebook of Current Theory, Research, and Therapy (pp. 1-10). New York: A Willey-Interscience Publication, John Willey \& Sons.

Perlman, D., \& Peplau, L. A. (1981). Toward a Social Psychology of Loneliness. In R. Duck, \& R. Gilmour (Eds.), Personal Relationships in Disorder (pp. 31-56). London: Academic Press.

Przepiorka, A., Blachnio, A., \& Diaz-Morales, J.F. (2016). Problematic Facebook use and Procrastination. Computers in Human Behavior, 65(2016), 59-64. https://doi.org/10.1016/j.chb.2016.08.022

Rothblum, E. D., Solomon, L. J., \& Murakami, J. (1986). Affective, cognitive, and behavioral differences between high and low procrastinators. Journal of Counseling Psychology, 33, 387-394. https://doi.org/10.1037/0022-0167.33.4.387

Solomon, L. J., \& Rothblum, E. D. (1984). Academic Procrastination: Frequency and Cognitive-Behavioral Correlates. Journal of Counseling Psychology, 31(4), 503-509. https://doi.org/10.1037/0022-0167.31.4.503

Song, H., Zymslinski-Seelig, A., Kim, J., Drent, A., Victor, A., Omori, K., \& Allen, M. (2014). Does Facebook make you lonely? A meta analysis. Computers in Human Behavior, 36(2014), 446-452.

https://doi.org/10.1016/j.chb.2014.04.011

Steel, P. (2007). The Nature of Procrastination: AMeta-Analytic and Theretical Review of Quintessential Self-Regulatory Factor . Psychological Bulletin, 133(1), 65-94. https://doi.org/10.1037/0033-2909.133.1.65

Steel, P., \& Klingsieck, K. (2016). Academic Procrastination: Psychological Antecedents Revisited. Australian Psychologist, 51((2016)), 36-46. https://doi.org/10.1111/ap.12173

Steel, P., Brothen, T., \& Wambach, C. (2001). Procrastination and personality, performance, and mood. Personality and Individual Differences, 30(2001), 95-106. https://doi.org/10.1016/S0191-8869(00)00013-1

Tharayil, D. P. (2012). Developing the University of Philipines Loneliness Assessment Scale: A Cross-Cultural Measurement. Soc. Indic Res, 106(2012), 307-321. https://doi.org/10.1007/s11205-011-9805-x

Tuckman, B. W. (1991). The Development and Concurrent Validity on Procrastination Scale. Educational and 
Psychological Measurement, 51, 473-480. https://doi.org/10.1177/0013164491512022

Yellowless, P. M., \& Marks, S. (2007). Problematic Internet use or Internet addiction? Computers in Human Behavior, 23(2007), 1447-1453. https://doi.org/10.1016/j.chb.2005.05.004

Young, K., Yue, X. D., \& Ying, L. (2011). Prevalence Estimates and Etiologic Models of Internet Addiction. In K. Young, \& C. N. de Abreu (Eds.), Internet Addiction. A Handbook and Guide to Evaluation and Treatment (pp. 3-18). New Jersey: John Wiley \& Sons.

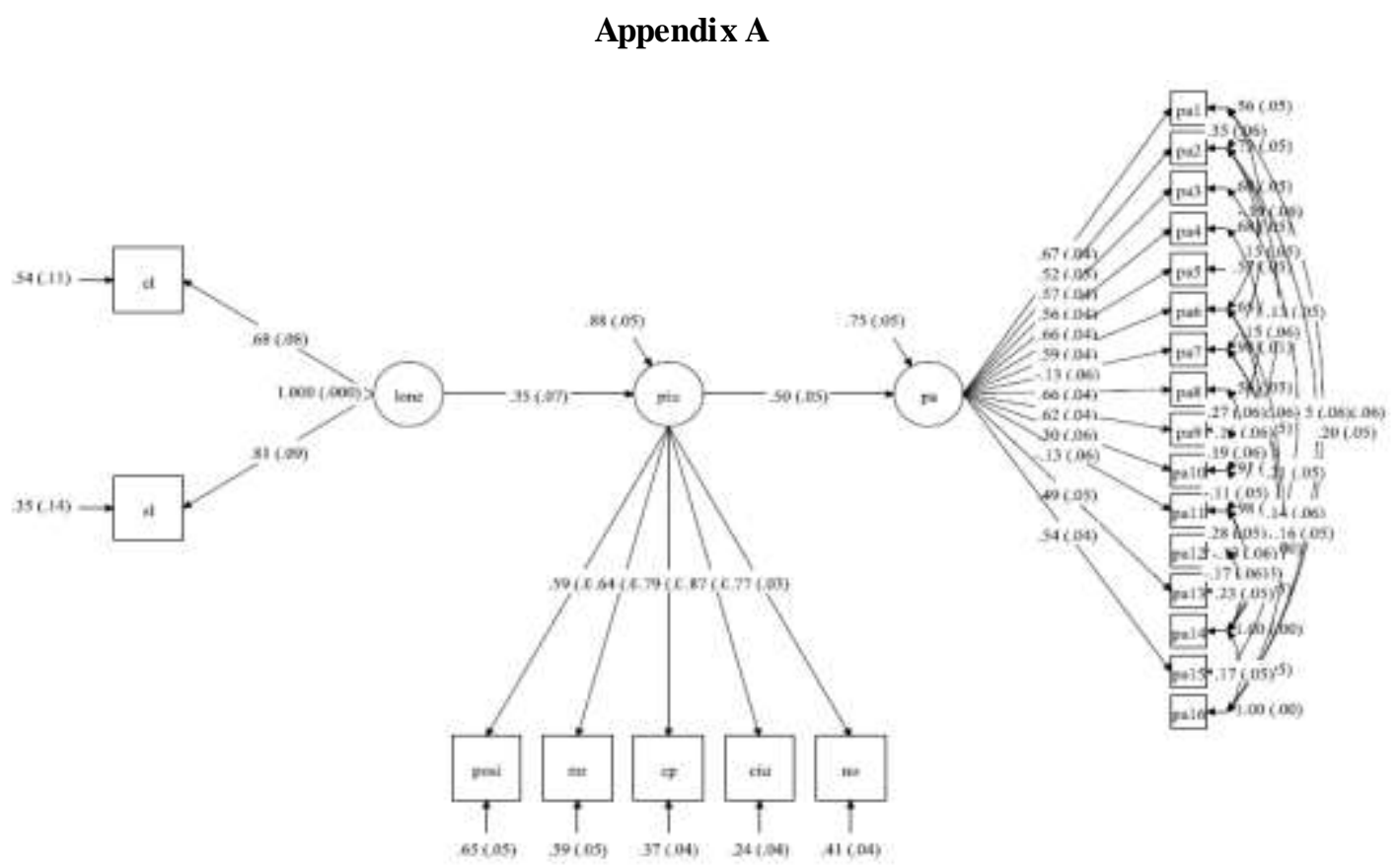

\section{Copyrights}

Copyright for this article is retained by the author(s), with first publication rights granted to the journal.

This is an open-access article distributed under the terms and conditions of the Creative Commons Attribution license which permits unrestricted use, distribution, and reproduction in any medium, provided the original work is properly cited. 